\title{
The role of oxide interlayers in back reflector configurations for amorphous silicon solar cells
}

\author{
V. Demontis, ${ }^{1}$ C. Sanna, ${ }^{1}$ J. Melskens, ${ }^{2}$ R. Santbergen, ${ }^{2}$ A. H. M. Smets,${ }^{2}$ A. Damiano, ${ }^{1}$ \\ and M. Zeman ${ }^{2}$ \\ ${ }^{1}$ Laboratorio Fotovoltaico, Sardegna Ricerche, Z.I. Macchiareddu 09010 Uta (CA), Italy \\ ${ }^{2}$ Photovoltaic Materials and Devices Laboratory-DIMES, Delft University of Technology, 2600 GA Delft, \\ The Netherlands
}

(Received 26 September 2012; accepted 23 January 2013; published online 13 February 2013)

\begin{abstract}
Thin oxide interlayers are commonly added to the back reflector of thin-film silicon solar cells to increase their current. To gain more insight in the enhancement mechanism, we tested different back reflector designs consisting of aluminium-doped zinc oxide ( $\mathrm{ZnO}: \mathrm{Al}$ ) and/or hydrogenated silicon oxide $\left(\mathrm{SiO}_{\mathrm{x}}: \mathrm{H}\right)$ interlayers with different metals (silver, aluminium, and chromium) in standard $p-i-n$ a-Si:H solar cells. We use a unique inverse modeling approach to show that in most back reflectors the internal metal reflectance is lower than expected theoretically. However, the metal reflectance is increased by the addition of an oxide interlayer. Our experiments demonstrate that $\mathrm{SiO}_{\mathrm{x}}: \mathrm{H}$ forms an interesting alternative interlayer because unlike the more commonly used $\mathrm{ZnO}: \mathrm{Al}$ it can be deposited by plasma-enhanced chemical vapour deposition and it does not reduce the fill factor. The largest efficiency enhancement is obtained with a double interlayer of $\mathrm{SiO}_{\mathrm{x}}: \mathrm{H}$ and ZnO:Al. @ 2013 American Institute of Physics. [http://dx.doi.org/10.1063/1.4790875]
\end{abstract}

\section{INTRODUCTION}

It is a well-known empirical fact that the short-circuit current density $\left(J_{s c}\right)$ of $p-i-n$ hydrogenated amorphous silicon (a-Si:H) solar cells increases by at least $1 \mathrm{~mA} / \mathrm{cm}^{2}$ if a thin aluminium-doped zinc oxide ( $\mathrm{ZnO}: \mathrm{Al})$ interlayer is deposited onto n-type a-Si:H before depositing the silver $(\mathrm{Ag})$ back reflector (BR). ${ }^{1-5}$ Interlayers based on $n$-type nanocrystalline hydrogenated silicon oxide $\left(\mathrm{SiO}_{\mathrm{x}}: \mathrm{H}\right)$ have been considered as well. ${ }^{6-8}$ External quantum efficiency (EQE) measurements indicate that the addition of the interlayer significantly increases the red response of the solar cell, which suggests that the BR reflectance increases. It has been proposed that this can be explained by constructive interference in the $\mathrm{ZnO}: \mathrm{Al} .{ }^{9}$ However, calculations based on the optical constants of $\mathrm{Ag}$ predict a reflectance of the a-Si:H/Ag interface as high as $94 \%$. Constructive interference in $\mathrm{ZnO}: \mathrm{Al}$ can increase the reflectance of the a-Si:H/Ag interface only slightly, so this cannot explain the significant improvements in the red response.

Furthermore, optical modeling of the a-Si:H/Ag interface has proven to be difficult. Opto-electrical models that use the theoretical reflectance of $94 \%$ tend to overestimate the red response of the solar cell. ${ }^{10,11}$ Remarkably, for solar cells with a $\mathrm{ZnO}: \mathrm{Al}$ interlayer, the use of the theoretical value of the reflectance does give accurate simulation results. This strongly indicates that in reality the reflectance of the a$\mathrm{Si}: \mathrm{H} / \mathrm{Ag}$ interface is far below $94 \%$. Because the mechanism causing the reduced reflectance is not completely understood, it is difficult to take this effect into account in optical models for solar cells. An effective, but not very elegant, way to correct the model is to add a thin aluminium layer to the BR. ${ }^{10,12}$

Several explanations have been suggested for the reduced reflectance of the a-Si:H/Ag interface. One is that $\mathrm{Ag}$ can diffuse into the a-Si:H $n$-layer resulting in a poorly defined interface. In this case, the effect of inserting an interlayer would be to prevent the diffusion of $\mathrm{Ag}$ and to keep the $\mathrm{Ag}$ interface sharp. ${ }^{13}$ Another explanation is that plasmonic absorption in $\mathrm{Ag}$ is responsible for the lower reflectance. ${ }^{14-16}$ In this case, the role of an interlayer would be to shift the plasmon resonance to shorter wavelengths where the a-Si:H layer is not transparent. Thus far, there is no conclusive evidence supporting either of the above explanations. It is also unknown whether similar effects occur for other combinations of metals and interlayers.

The objective of this work is to gain more insight in the physical mechanisms affecting the reflectance of $\mathrm{Ag}$ in the BR of a-Si:H solar cells. We will not limit ourselves to Ag, but we will study several metal/interlayer combinations. In this way, we assess the suitability of different combinations that can be used as BR in a-Si:H solar cells. As the BR also has the role of an electrical contact, both its optical and electrical properties need to be considered.

Going from $\mathrm{Ag}$ to $\mathrm{Al}$ and finally to chromium $(\mathrm{Cr})$, the ability of the metal to support plasmon resonance decreases from very high to very low. Therefore, we use these three metals to investigate to which extent plasmonic effects play a role in the a-Si:H/Ag interface reflectance. As interlayer material, we consider both $\mathrm{ZnO}: \mathrm{Al}$ and $\mathrm{SiO}_{\mathrm{x}}: \mathrm{H}$. The commonly used $\mathrm{ZnO}: \mathrm{Al}$ requires sputter deposition, while $\mathrm{SiO}_{\mathrm{x}}: \mathrm{H}$, just like the a-Si:H layers, can be deposited by radio frequency plasma-enhanced chemical vapour deposition (rfPECVD). Therefore, if $\mathrm{SiO}_{\mathrm{x}}: \mathrm{H}$ could replace the $\mathrm{ZnO}: \mathrm{Al}$ layer in the BR, the solar cell fabrication process would be simplified. By considering double interlayers containing both a $\mathrm{ZnO}: \mathrm{Al}$ and a $\mathrm{SiO}_{\mathrm{x}}: \mathrm{H}$ layers, we also study the effect of refractive index grading. The uniqueness of our study is that by combining three different metals and five interlayer configurations, we obtain 15 different BR structures. In order 
to carefully investigate both the optical and electrical effects, we process complete a-Si:H solar cells with these BR structures at the back side of the solar cells and measure the external solar cell parameters using a minimum number of deposition runs for the $p-i-n$ structures.

\section{EXPERIMENTAL DETAILS}

The different BRs considered in this study were tested on $p-i-n$ single junction a-Si:H solar cells, deposited according to a standard recipe. Samples were prepared by rf-PECVD using both flat and textured substrates. Samples deposited on flat substrates were used for the study of the BR reflectance through optical simulations, while samples deposited on textured substrates were used to analyse the effect of different BR configurations on the performance of the solar cells.

The structure of the standard solar cell, both for the flat and the textured samples, is as follows: glass/transparent conductive oxide $(\mathrm{TCO}) / p$-type $\mu \mathrm{c}-\mathrm{Si}: \mathrm{H}(5 \mathrm{~nm}) / p$-type a$\mathrm{SiC}: \mathrm{H}(7 \mathrm{~nm}) / \mathrm{a}-\mathrm{SiC}: \mathrm{H}$ buffer $(5 \mathrm{~nm}) / i$-type a-Si:H $(300 \mathrm{~nm}) /$ $n$-type a-Si:H (20 nm). On this standard solar cell, we deposited several BR configurations by combining different oxide interlayers and different metals. As interlayers, we considered a $60 \mathrm{~nm} \mathrm{ZnO}: \mathrm{Al}$ layer and/or a $30 \mathrm{~nm}$ n-type $\mathrm{SiO}_{\mathrm{x}}: \mathrm{H}$ layer. $\mathrm{ZnO}: \mathrm{Al}$ was sputtered from a zinc oxide $(\mathrm{ZnO})$ ceramic target with 2 wt. \% alumina $\left(\mathrm{Al}_{2} \mathrm{O}_{3}\right) . \mathrm{SiO}_{\mathrm{x}}: \mathrm{H}$ was deposited by rf-PECVD, using silane $\left(\mathrm{SiH}_{4}\right)$, carbon dioxide $\left(\mathrm{CO}_{2}\right)$, hydrogen $\left(\mathrm{H}_{2}\right)$, and phosphine $\left(\mathrm{PH}_{3}\right)$ as precursor gases. An optimisation of the material has previously been performed in order to achieve the highest solar cell performances. $\mathrm{SiO}_{\mathrm{x}}: \mathrm{H}$ layers deposited according to the optimised recipe show a microcrystalline morphology, with crystalline grains embedded in an amorphous matrix. A detailed analysis of the microstructure showed an oxygen content of $55.9 \%$ and a crystalline fraction of $61 \%$. Optical characterisation revealed a bandgap of $2.8 \mathrm{eV} .{ }^{17}$

On the total area of each sample $(10 \mathrm{~cm} \times 2.5 \mathrm{~cm}), 30$ individual solar cells were made, each with an area of $0.16 \mathrm{~cm}^{2}$, as defined by the size of the metal back contact. In order to have well-defined contact areas, the remaining oxides around the contact were removed by wet $(\mathrm{ZnO}: \mathrm{Al})$ and dry plasma $\left(\mathrm{SiO}_{\mathrm{x}}: \mathrm{H}\right)$ etching. Three metals were deposited according to the scheme shown in Fig. 1(b). In this way, for every BR configuration, we obtained 10 solar cells distributed uniformly over the sample surface, allowing for good statistics on the solar cell external parameters presented in this study.

As metals, we considered $\mathrm{Ag}, \mathrm{Al}$, and $\mathrm{Cr}$ evaporated using a Provac PRO500S system with a deposition rate of $1 \mathrm{~nm} / \mathrm{s}$ and no substrate heating. The metals are part of the $\mathrm{BR}$ and serve as back contacts. To eliminate the influence of small differences in the deposition conditions that may exist between different deposition runs, we will only compare samples deposited in the same run. While keeping the basic solar cell structure fixed as described above, we prepared different sets of samples.

For the optical study, we deposited the above-described $p$ - $i$ - $n$ structure also on flat substrates $(0.7 \mathrm{~mm}$ thick Corning Eagle XG glasses with a $1 \mu \mathrm{m}$ thick $\mathrm{ZnO}$ :Al layer as a front TCO) in a single deposition run. An AFM scan of the flat $\mathrm{ZnO}: \mathrm{Al}$ layer confirmed that the rms roughness of this layer is less than $5 \mathrm{~nm}$. Three different BR configurations were applied to these samples resulting in one solar cell with just the metal as BR (flat reference solar cell), one solar cell with a $\mathrm{SiO}_{\mathrm{x}}: \mathrm{H} / \mathrm{metal} \mathrm{BR}$, and one solar cell with a $\mathrm{ZnO}: \mathrm{Al} / \mathrm{metal}$ $\mathrm{BR}$. For all these samples, $\mathrm{Ag}, \mathrm{Al}$, and $\mathrm{Cr}$ metal back contacts were deposited according to the scheme shown in Fig. 1(b). The total reflectance $(R)$ and transmittance $(T)$ of these samples were measured as a function of the wavelength from $300 \mathrm{~nm}$ to $1200 \mathrm{~nm}$ using a PerkinElmer Lambda 950 spectrophotometer equipped with an integrating sphere. The standard spot size was reduced, allowing $R$ and $T$ measurements to be done on individual $0.16 \mathrm{~cm}^{2}$ solar cells or on the semitransparent spacing in between the metal back contacts.

The optical simulations were performed using the one dimensional (1-D) opto-electrical simulation tool Advanced Semiconductor Analysis (ASA) ${ }^{18}$ developed at Delft University of Technology. The optical model is based on the transfer matrix method.

To study the role of different BR configurations on the performance of the solar cells, two runs of solar cell were
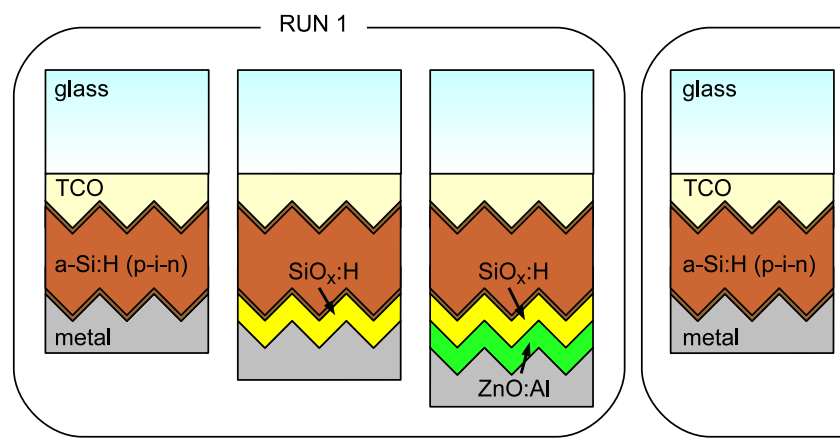

RUN 2
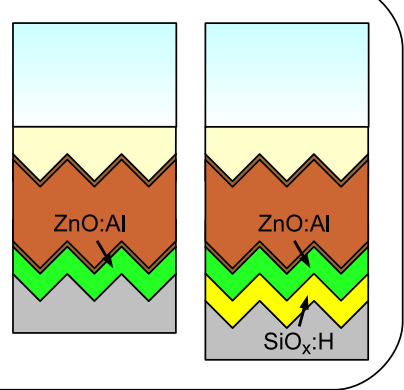

(a)

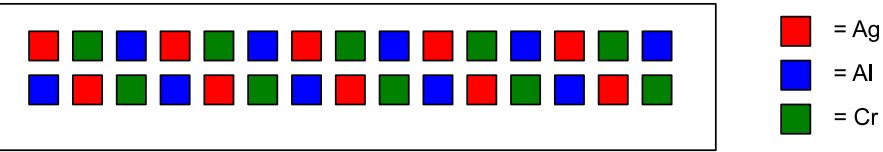

FIG. 1. (a) Scheme of the two sets of deposited solar cells. (b) Distribution of different metal back contacts (Ag, Al, and $\mathrm{Cr}$ ) on the total area of each solar cell test strip. 


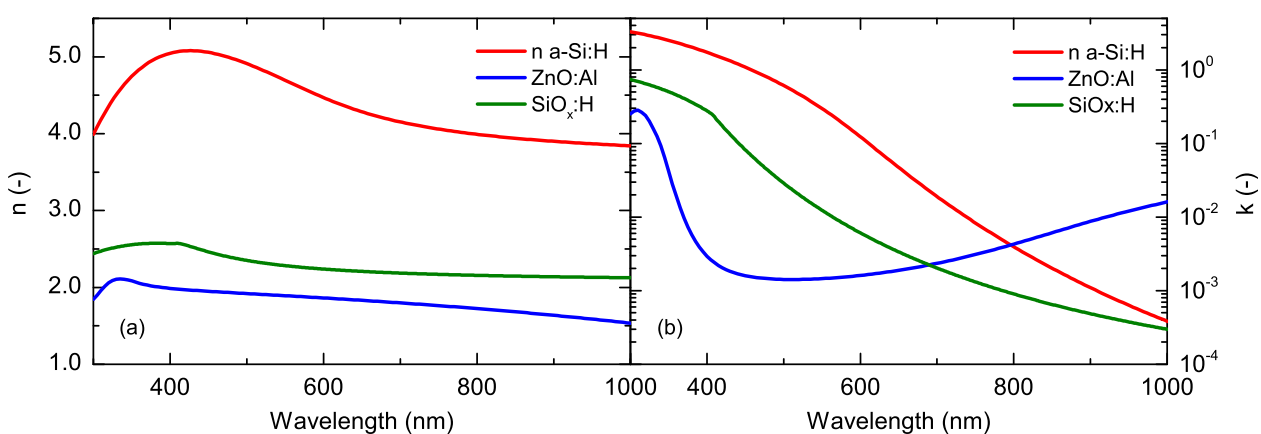

FIG. 2. Measured values of (a) $n$ and (b) $k$ as a function of wavelength for n-type a-Si:H, $\mathrm{ZnO}: \mathrm{Al}$, and $\mathrm{SiO}_{\mathrm{x}}: \mathrm{H}$. deposited on textured Asahi VU-type substrates (see Fig. 1(a)). The first run includes one reference sample with only a metal $\mathrm{BR}$, one sample with a $\mathrm{SiO}_{\mathrm{x}}: \mathrm{H} /$ metal $\mathrm{BR}$, and one sample with a $\mathrm{SiO}_{\mathrm{x}}: \mathrm{H} / \mathrm{ZnO}: \mathrm{Al} /$ metal $\mathrm{BR}$. The second run includes again a reference sample, one sample with a $\mathrm{ZnO}: \mathrm{Al} /$ metal $\mathrm{BR}$, and one sample with a $\mathrm{ZnO}: \mathrm{Al} / \mathrm{SiO}_{\mathrm{x}}: \mathrm{H} /$ metal BR. Note that the double interlayer configuration of this second run is inverted with respect to the double interlayer configuration in the first run.

All the 30 individual solar cells of each sample were characterised by J-V measurements under AM 1.5 illumination using a PASAN flash solar simulator and by EQE in the wavelength range of $300-850 \mathrm{~nm}$. All solar cell external parameters presented in this article are the average values of the best 5 solar cells (in terms of conversion efficiency). The averaged $J_{s c}$ values are calculated by integration of the EQE and are used to correct the conversion efficiency obtained from $\mathrm{J}-\mathrm{V}$ measurements. The maximum error on the averaged external parameters will be indicated by error bars.

\section{RESULTS}

\section{A. Metal reflectance}

As a first step, we investigate the reflectance of the different metals. Note that we are interested in the internal reflectance, i.e., the reflectance of the back metal inside the solar cell at the a-Si:H/metal interface. For this part of our study, we compare 1D optical simulations and experimental reflectance and transmittance measurements performed on samples deposited on flat substrates, as mentioned in Sec. II. We focus on flat samples with smooth interfaces because simulation of light scattering at textured interfaces requires an accurate knowledge of the scattering parameters such as haze and angular intensity distribution, ${ }^{11}$ which cannot be determined with sufficient accuracy for our purpose. In case of these samples, the only roughness is the one that is naturally introduced during the growth of the layers, which is sufficiently small to consider the interfaces optically flat in our metal reflectance study.

For wavelengths larger than $600 \mathrm{~nm}$, the a-Si:H layers are transparent and the solar cell's external reflectance, measured from the front side of the solar cell, depends partly on the internal metal reflectance. To derive the internal metal reflectance from the solar cell's external reflectance, we use an optical model that takes the absorption in each layer and interference effects into account. This model requires the refractive index (real part $n$ and imaginary part $k$ ) and the thickness of each layer as input parameters. The optical properties of the layers ( $n$ and $k$ ) used for the simulation are determined from $(R, T)$ measurements on individual layers deposited on glass, deposited separately for this purpose. The measured $n$ and $\mathrm{k}$ values as a function of wavelength of n-type a-Si:H, ZnO:Al, and $\mathrm{SiO}_{\mathrm{x}}: \mathrm{H}$ are shown in Fig. 2. The optical properties of the metals are taken from literature. ${ }^{19}$ For every solar cell, $n$ and $k$ and the thickness of each layer used in the model are validated. For this purpose, $R$ and $T$ of the solar cells are measured in between the metal back contact dots as shown in Fig. 3(c). In this way, we first consider the solar cell without BR. $R$ and $T$ are measured once from the front side and once from the back side of the solar cell (see Figs. 3(a) and 3(b), respectively). In both graphs, the measured values of $1-R$ (red symbols) and $T$ (blue symbols)

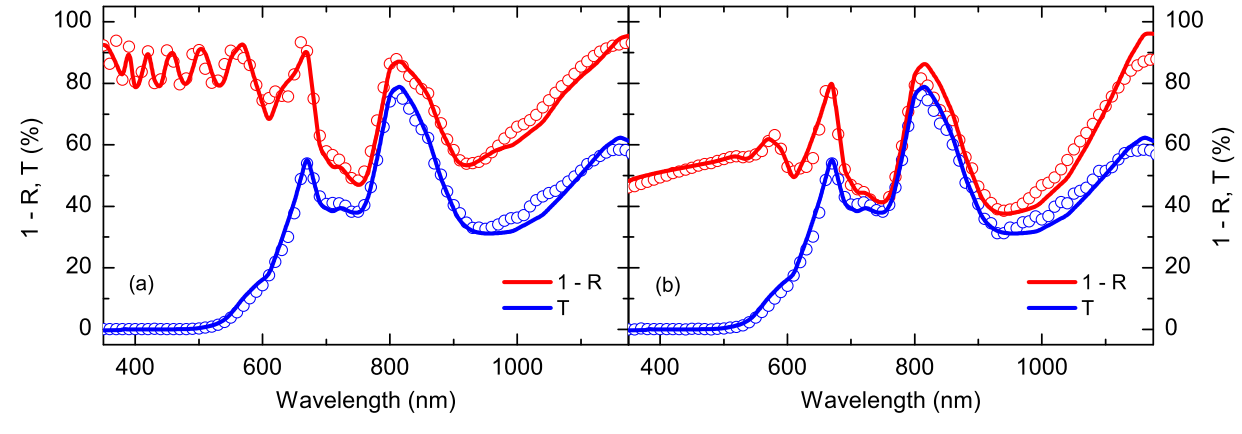

(c)

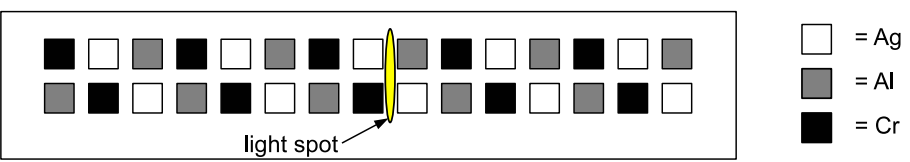

FIG. 3. $R$ and $T$ as a function of wavelength for the reference solar cell. Solid lines indicate the simulations, and circles the experimental results for (a) glass side illumination and (b) back side illumination. In the scheme depicted in (c), the position of the light spot in the spectrophotometer used for the $R$ and $T$ measurements in between the dots is indicated. 
are plotted. In this way, the absorptance $(A=1-R-T)$ can be observed directly as the difference between the two curves. For wavelengths above $550 \mathrm{~nm}$, the sample is transparent and $T$ increases to values up to $80 \%$. Note that, as expected, $T$ is the same for both illumination sides, while $R$ is not. The fringes are due to interference in the front TCO and a-Si:H layers, and these are very sensitive to the exact layer thicknesses. Then $R$ and $T$ of this semitransparent structure are simulated as well. Note that because the measurement is done in between the metal dots, we simulate the solar cell structure without the metal. The thicknesses of the front TCO and the absorber layer are varied slightly from the values calculated from the deposition rate in order to obtain a good agreement between the measured and simulated $R$ and $T$. The simulation results are indicated as solid lines. The excellent agreement for both illumination sides is an indication of the validity and accuracy of the model and of the optical constants (shown in Fig. 2) and layer thicknesses used.

As a next step, we measured the reflectance from the front side of the solar cells, i.e., on the metal dots instead of in between them. First, we consider the reference solar cells without the interlayer. The measured solar cell reflectances for $\mathrm{Ag}, \mathrm{Al}$, and $\mathrm{Cr}$ BRs are shown as symbols in Fig. 4. The validated model is used to simulate the total reflectance of the solar cells now including the metal BR. For wavelengths shorter than $600 \mathrm{~nm}$, most of the light is absorbed before reaching the $\mathrm{BR}$ and the reflectance is low, but for longer wavelengths, a-Si:H is transparent and the reflectance is highly dependent on the BR used. Without modifying the optical constants or thickness of any of the layers, we now add a metal layer as the back contact in the simulation. The model uses the $n$ and $k$ values of $\mathrm{Ag}, \mathrm{Al}$, and $\mathrm{Cr}$ found in literature $^{19}$ as input for the Fresnel equations to determine the corresponding metal reflectance. These theoretical reflectance values are shown in brackets in Table I. The simulation results deviate somewhat from the experimental results, as illustrated in Fig. 4. Because there is an excellent agreement between the simulation and experimental results shown in Fig. 3, the deviation between measurement and simulation in Fig. 4 can only be caused by the introduction of the metal layer in the simulation. This indicates that simply calculating the reflectance from the optical constants of the metals can

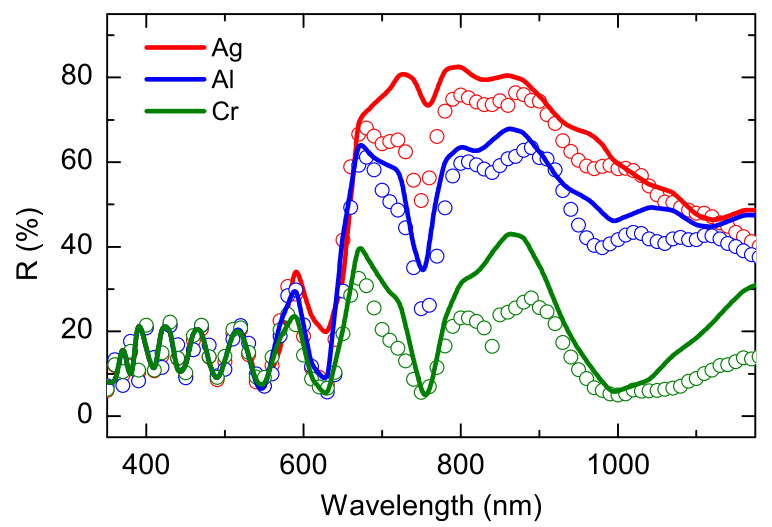

FIG. 4. Experimental and calculated total reflectance of the reference solar cell (Ag, Al, and Cr back contacts). Circles represent experimental measurements, and solid lines represent the simulation results obtained by using literature $\mathrm{n}$ and $\mathrm{k}$ values for the metals. ${ }^{19}$
TABLE I. Experimental reflectance for $\mathrm{Ag}, \mathrm{Al}$, and $\mathrm{Cr}$ in different $\mathrm{BR}$ configurations. Theoretical values are given in brackets.

\begin{tabular}{llll}
\hline \hline & a-Si:H/metal & $\mathrm{SiO}_{\mathrm{x}}: \mathrm{H} /$ metal & $\mathrm{ZnO}: \mathrm{Al} / \mathrm{metal}$ \\
\hline $\mathrm{Ag}$ & $0.86(0.94)$ & $0.95(0.96)$ & $0.93(0.96)$ \\
$\mathrm{Al}$ & $0.62(0.75)$ & $0.73(0.84)$ & $0.73(0.87)$ \\
$\mathrm{Cr}$ & $0.08(0.23)$ & $0.11(0.39)$ & $0.14(0.48)$ \\
\hline \hline
\end{tabular}

lead to an overestimation of the total reflectance. This is in agreement with earlier results. ${ }^{10,12}$

To correct the simulations, we can artificially reduce the reflectance of the metal in the model. In order to do this, we adapt the optical model to allow the metal reflectance value to be given as input directly, instead of being calculated from the Fresnel equations. In the wavelength range of 600$1200 \mathrm{~nm}$, the reflectances of $\mathrm{Ag}, \mathrm{Al}$, and $\mathrm{Cr}$ are reasonably constant. Therefore, for simplicity, we consider the metal reflectance to be independent of the wavelength. We assume that the reflectance value that gives the best fit with the experimental data is the most realistic. In this way, we have obtained a unique inverse modeling approach to accurately determine the internal metal reflectance in our solar cells. Note that this internal reflectance cannot be measured directly.

In Fig. 5(a), we present the results for the reference solar cell with Ag BR. A comparison between Figs. 4 and 5(a) shows that the measured solar cell reflectance can be approximated much better by assuming a constant Ag reflectance of $86 \%$. In the same way, we determine that for the solar cell with a $\mathrm{SiO}_{\mathrm{x}}: \mathrm{H} / \mathrm{Ag} \mathrm{BR}$ the $\mathrm{Ag}$ reflectance is about 95\% (see Fig. 5(b)). Although not displayed here, an equally good fit was found for the solar cell with a $\mathrm{ZnO}: \mathrm{Al}$ interlayer using a Ag reflectance of $93 \%$. Note that these are the internal reflectance values of just the metal and not of the complete BR which also includes an a-Si:H/interlayer interface.

The same analysis is performed for the other metals. As can be seen from the theoretical values given in brackets in Table I, Al is expected to have a somewhat lower reflectance than $\mathrm{Ag}$. $\mathrm{Cr}$ is expected to have an even lower reflectance. It follows from the Fresnel equations that for an adjacent material with a high refractive index, such as a-Si:H, the metal reflectance is the lowest. Especially, for metals such as $\mathrm{Al}$ and $\mathrm{Cr}$ with a relatively high $n$, this effect reduces the metal reflectance significantly. The experimental values derived from the reflectance measurements, given in Table I, are somewhat lower than the theoretical values but show the same trend. Also for $\mathrm{Al}$ and $\mathrm{Cr}$, the addition of an oxide increases the metal reflectance. However, unlike Ag, the reflectance values of $\mathrm{Al}$ and $\mathrm{Cr}$ do not recover to the theoretical values and remain rather low. The origin of this behaviour is not clear at the moment.

For this optical study, we have used flat solar cells (i.e., solar cells deposited on flat substrates) that could be modeled very well. This supports the idea that the main phenomenon involved in metal reflectance reduction is not related to surface roughness or texturisation. Therefore, it is unlikely that the main contribution to the reduction of the reflectance of the metals observed here is due to plasmonic excitation. The 


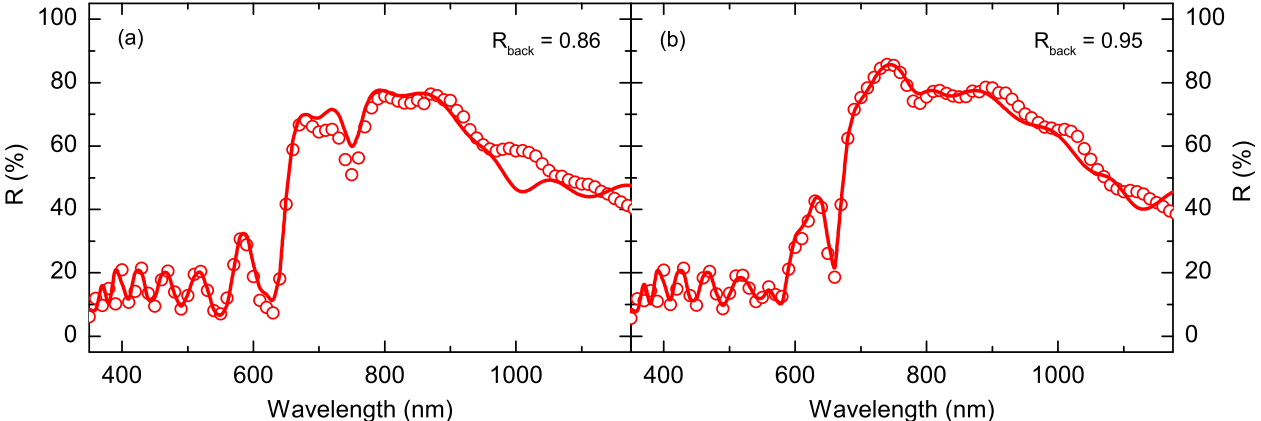

FIG. 5. Simulation of the total reflectance of the solar cells (Ag back contacts). (a) Reference solar cell. (b) Solar cell with $\mathrm{SiO}_{\mathrm{x}}: \mathrm{H} /$ metal BR. alternative explanation that the reflectance is reduced because the metal interface is not perfectly sharp seems more likely. Regardless of the physical mechanism, a correction is required in optical models for accurate modeling of the BR in a-Si:H solar cells. The experimental reflectance values summarised in Table I can be used instead of the theoretical values given in brackets. The comparison between $\mathrm{SiO}_{\mathrm{x}}: \mathrm{H}$ and $\mathrm{ZnO}: \mathrm{Al}$ shows that both interlayers increase $R$ and perform equally well. Therefore, from a purely optical point of view, the fabrication process of the BR could be simplified by replacing the commonly used $\mathrm{ZnO}: \mathrm{Al}$ by $\mathrm{SiOx}: \mathrm{H}$ which can be deposited by PECVD.

\section{B. Solar cell performance}

As a next step, we investigate the role of different metals as back contacts in a-Si:H solar cells in order to analyse their effect on the solar cell external parameters. In this case, we focus on textured Asahi VU-type substrates, which are commonly used in a-Si:H solar cells. In this way, we can evaluate whether the results obtained in the simulation study on flat samples are coherent when the BR is applied on textured interfaces.

The comparison between the EQE of three solar cells that have $\mathrm{Ag}, \mathrm{Al}$, or $\mathrm{Cr}$ as metal back contacts is shown in Fig. 6. Only the results for the solar cells without oxide interlayer between the silicon layers and the metal are reported, because similar behaviour is observed for the solar cells with oxide interlayer(s) in the BR. For short wavelengths, the three curves have the same behaviour because all photons in this wavelength range are absorbed in the a-Si:H layers and

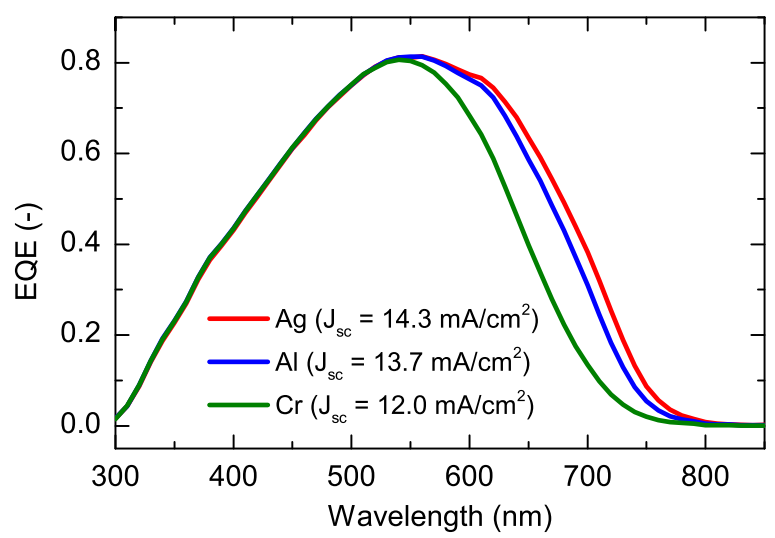

FIG. 6. Comparison between the EQE of three reference solar cells with Ag, $\mathrm{Al}$, and $\mathrm{Cr}$ as metal back contacts. do not reach the BR. Different behaviours are observed for longer wavelengths, where the type of metal influences the performance of the solar cells. As demonstrated by the differences in red response, it is clear that the most effective metal back contact is Ag, because of its high reflectance, followed by $\mathrm{Al}$, and finally $\mathrm{Cr}$. The corresponding $J_{s c}$ values are given in Fig. 6. This result is in agreement with other studies reported in literature. $^{20}$

For the two most commonly used metals ( $\mathrm{Ag}$ and $\mathrm{Al}$ ), we show the effect of additional oxide interlayer(s) on the solar cell parameters. The open circuit voltage $\left(V_{o c}\right)$ is not reported because no significant variations have been observed by changing the BR configuration. For every solar cell considered in this work, $V_{o c}=0.859 \pm 0.003 \mathrm{~V}$. The conversion efficiency $(\eta)$, the fill factor $(F F)$, and $J_{s c}$ of the solar cells of the first run are reported in Figs. 7(a)-7(c), respectively. This first run includes one reference sample without interlayer, one sample with a $\mathrm{SiO}_{\mathrm{x}}: \mathrm{H}$ interlayer, and one sample with a $\mathrm{SiO}_{\mathrm{x}}: \mathrm{H} / \mathrm{ZnO}: \mathrm{Al}$ interlayer. The results for the solar cells with $\mathrm{Ag}$ and $\mathrm{Al}$ as back metal contact are shown, respectively, on the left and on the right in each graph. In agreement with earlier results, ${ }^{8}$ the insertion of a $\mathrm{SiO}_{\mathrm{x}}: \mathrm{H}$ interlayer between the silicon layers and the metal back contact improves $\eta$. The $\mathrm{SiO}_{\mathrm{x}}: \mathrm{H}$ interlayer increases $J_{s c}$ while leaving $F F$ unaffected. By adding a $\mathrm{ZnO}$ :Al layer between $\mathrm{SiO}_{\mathrm{x}}: \mathrm{H}$ and the back metal, we observe a further improvement in $\eta$. Both for $\mathrm{Ag}$ and $\mathrm{Al}$, this enhancement is again due to an increase in $J_{s c}$ and also in this case $F F$ is not affected.

The $J_{s c}$ improvement can also be seen in the EQE measurement shown in Fig. 7(d). The effect of the BRs is visible as an enhancement response in the long wavelength range $(550-850 \mathrm{~nm})$ with respect to the reference solar cell without oxide interlayers. We can observe that the solar cell with the double $\mathrm{SiO}_{\mathrm{x}}: \mathrm{H} / \mathrm{ZnO}: \mathrm{Al}$ interlayer has a slightly higher red response in the EQE than the solar cell with the single $\mathrm{SiO}_{\mathrm{x}}: \mathrm{H}$ interlayer.

In Fig. 8, the external parameters of the solar cells of the second deposition run are shown. In this second run, we consider the $\mathrm{ZnO}: \mathrm{Al}$ interlayer and the $\mathrm{ZnO}: \mathrm{Al} / \mathrm{SiO}_{\mathrm{x}}: \mathrm{H}$ interlayer. Again we report only the results for the solar cells with $\mathrm{Ag}$ and $\mathrm{Al}$ as metal back contacts. As expected, the conversion efficiency of the solar cell with $\mathrm{ZnO}$ :Al interlayer improves with respect to the reference solar cell that has only a metal BR. Again the improvement is due to an enhancement in $J_{s c}$, but in this case, we note that $F F$ is reduced. This indicates that the $\mathrm{ZnO}: \mathrm{Al}$ interlayer introduces 

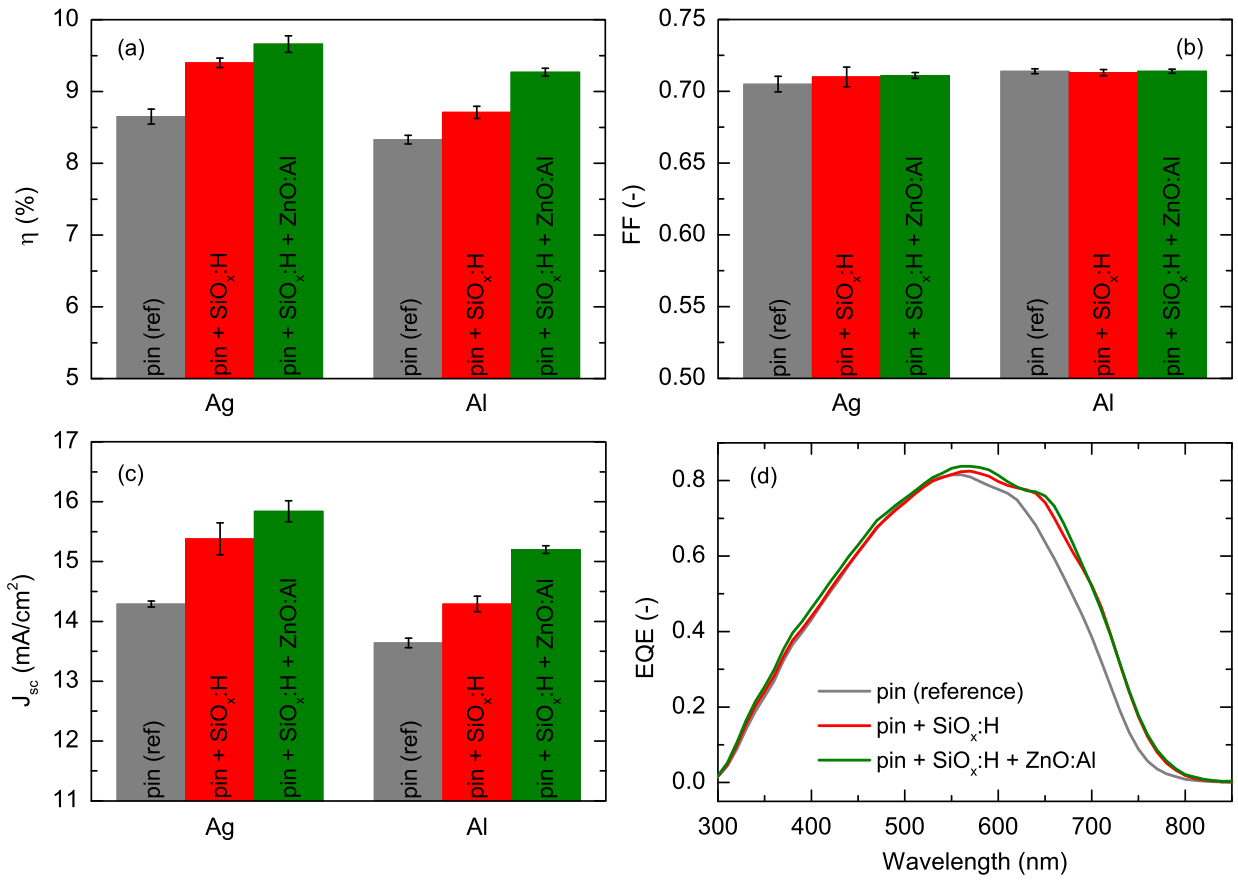

FIG. 7. Solar cell external parameters for the solar cells from run 1. (a) conversion efficiency, (b) fill factor, (c) short circuit current density (Ag back contact on the left, $\mathrm{Al}$ back contact on the right), and (d) external quantum efficiency for $\mathrm{Ag}$ metal contact solar cells.

a higher series resistance in the solar cell when compared to the series resistance in the solar cell that has a $\mathrm{SiO}_{\mathrm{x}}: \mathrm{H}$ interlayer.

Concerning the $\mathrm{ZnO}: \mathrm{Al} / \mathrm{SiO}_{\mathrm{x}}: \mathrm{H}$ interlayer, we observe that adding the $\mathrm{SiO}_{\mathrm{x}}: \mathrm{H}$ interlayer to the $\mathrm{ZnO}: \mathrm{Al}$ interlayer does not significantly increase $J_{s c}$. However, because $F F$ is significantly reduced, the additional $\mathrm{SiO}_{\mathrm{x}}: \mathrm{H}$ interlayer even causes a small decrease in $\eta$. This indicates that when $\mathrm{SiO}_{\mathrm{x}}: \mathrm{H}$ is deposited onto $\mathrm{ZnO}: \mathrm{Al}$ it does not form a good electrical contact. The inverted stack shown, where $\mathrm{ZnO}: \mathrm{Al}$ is deposited onto $\mathrm{SiO}_{\mathrm{x}}: \mathrm{H}$, does not create such problems (see Fig. 7). So, in case of the $\mathrm{ZnO}: \mathrm{Al} / \mathrm{SiO}_{\mathrm{x}}: \mathrm{H}$ interlayer, the improvement in solar cell performance is entirely due to the first oxide interlayer ( $\mathrm{ZnO}: \mathrm{Al})$ while the addition of the
$\mathrm{SiO}_{\mathrm{x}}: \mathrm{H}$ layer lowers the solar cell performance with respect to the single oxide interlayer configuration.

The improvement of $J_{s c}$ with respect to the reference solar cell due to the insertion of a $\mathrm{ZnO}: \mathrm{Al}$ interlayer can also be deduced from the EQE curves shown in Fig. 8(d). This confirms that the addition of $\mathrm{S} \mathrm{SiO}_{\mathrm{x}}: \mathrm{H}$ interlayer on top of a $\mathrm{ZnO}: \mathrm{Al}$ interlayer does not lead to a significant enhancement of the red response.

\section{DISCUSSION}

The metal reflectance derived from reflectance measurements on the flat samples shows a good correlation with the red response of the solar cells (deposited on Asahi UV-type
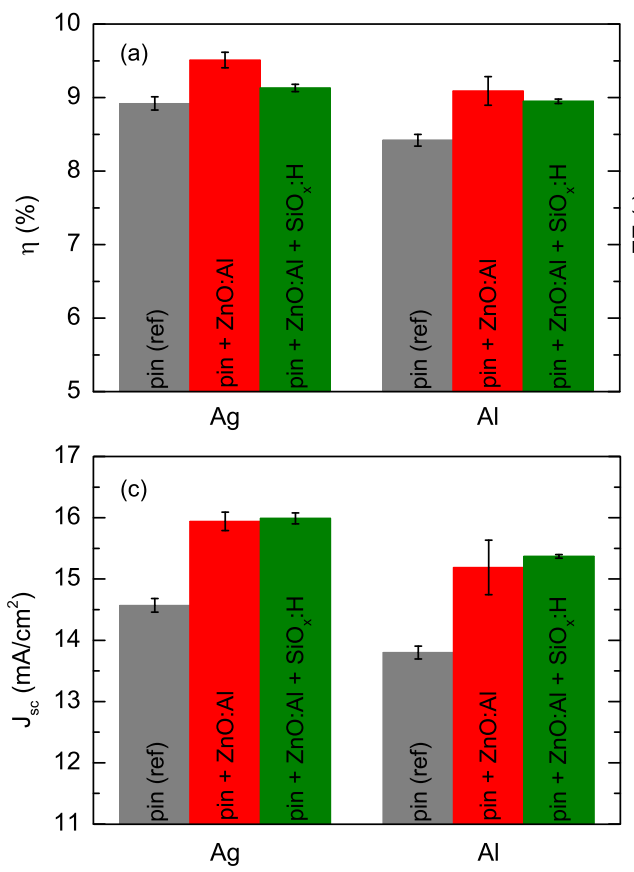
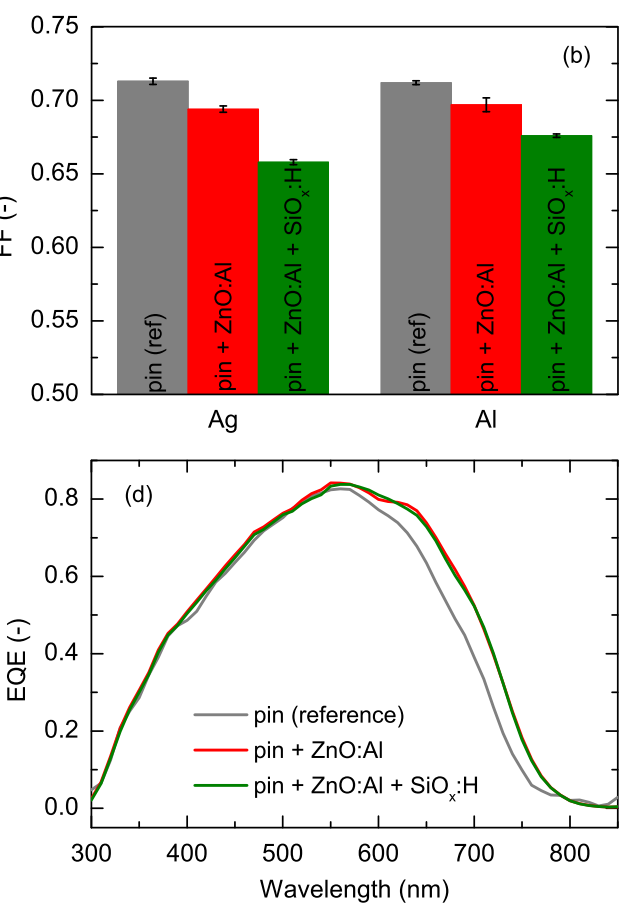

FIG. 8. Solar cell external parameters for the solar cells from run 2. (a) conversion efficiency, (b) fill factor, (c) short circuit current density (Ag back contact on the left, $\mathrm{Al}$ back contact on the right), and (d) external quantum efficiency for Ag metal contact solar cells. 
substrates), as characterised by EQE. The decrease in reflectance of the a-Si:H/metal interface when going from $\mathrm{Ag}$ to $\mathrm{Al}$ and finally to $\mathrm{Cr}$ corresponds with the decreasing red response of the solar cells for these three metals, as was already shown in Fig. 6. Furthermore, the observation that the addition of $\mathrm{SiO}_{\mathrm{x}}: \mathrm{H}$ or $\mathrm{ZnO}: \mathrm{Al}$ interlayers increases the reflectance of the metal is in agreement with the EQE curves shown in Figs. 7(d) and 8(d). This is quantified more precisely in Fig. 9 where the measured $J_{s c}$ in the long wavelength range is plotted versus the reflectance of the BR. The type of symbol indicates which interlayers are used, and the colour indicates the type of metal used in the BR. On the vertical axis $J_{s c,>550 \mathrm{~nm}}$ is shown, since it represents the short circuit current density generated in the wavelength range where the BR affects the red response of the solar cells. This excludes the small variations in the EQE curves at shorter wavelengths which cannot be attributed to the BR. The total reflectance of the BR reported here is obtained from the optical model. Compared to the metal reflectance, the total BR reflectance can include the reflectance of additional interfaces of the interlayers. The interference effects of the $30 \mathrm{~nm}$ thick $\mathrm{SiO}_{\mathrm{x}}: \mathrm{H}$ and $60 \mathrm{~nm}$ thick $\mathrm{ZnO}: \mathrm{Al}$ interlayers are taken into account.

Fig. 9 shows that the $\mathrm{Cr} \mathrm{BR}$, which has the lowest reflectance, also has the lowest red response at $J_{s c,>550 \mathrm{~nm}}$ $=5.9 \mathrm{~mA} / \mathrm{cm}^{2}$. The $\mathrm{SiO}_{\mathrm{x}}: \mathrm{H} / \mathrm{ZnO}: \mathrm{Al} / \mathrm{Ag}$ BR has the highest reflectance resulting in the highest red response of $J_{s c,>550 \mathrm{~nm}}=9.7 \mathrm{~mA} / \mathrm{cm}^{2}$. The dashed line indicates a linear trend line. Most BR configurations are close to this trend line, indicating that the red response of the solar cell is strongly correlated with the BR reflectance. We recall that the solar cells were fabricated on a rough substrate while the reflectances of the BR were derived from flat samples. If we assume that the red response of the solar cell increases linearly with its BR reflectance, then any deviation from the linear trend line may be caused by different changes in reflectance when going from a flat to a rough BR. Any data point significantly below the trend line corresponds to a BR which has an above average reflectance reduction when going from flat to rough. We point out that this is the case

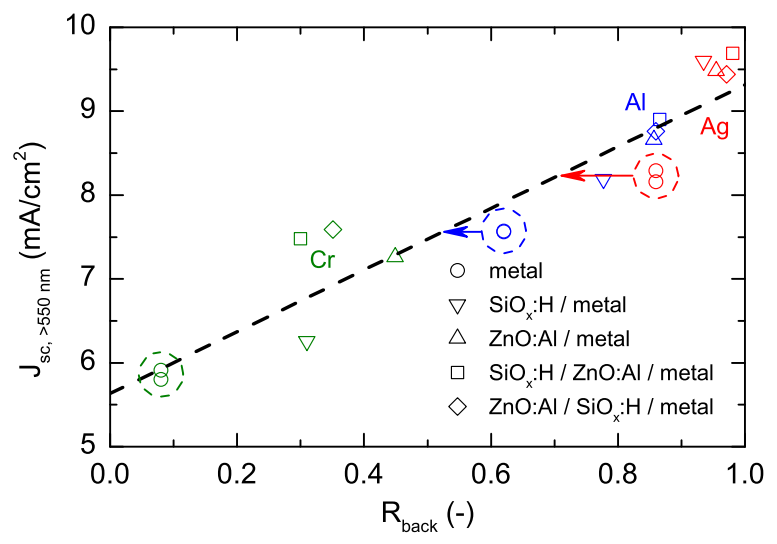

FIG. 9. The measured short circuit current density generated in the wavelength range where the BR affects the red response of the solar cells (550$850 \mathrm{~nm}$ ) as a function of the reflectance of a flat BR. The colours (green, blue, and red) indicate the metals used in the $\mathrm{BR}(\mathrm{Cr}, \mathrm{Al}$, and $\mathrm{Ag})$. The dashed line is a linear trend line fitted to all the points shown in the graph. for the $\mathrm{Ag}$ and $\mathrm{Al} \mathrm{BRs}$ without interlayer, as indicated by the red and blue arrows, respectively. We suspect that this could be related to the plasmonic absorption losses that can only occur on nanorough $\mathrm{Ag}$ and $\mathrm{Al}$ surfaces. Plasmons cannot be excited in a flat solar cell and on most other metals. If this is the case then the length of the arrows indicates the extent of the plasmonic absorption losses, being about $15 \%$ for $\mathrm{Ag}$ and $10 \%$ for Al. To explain why plasmonic absorption does not occur (or is reduced) when $\mathrm{SiO}_{\mathrm{x}}: \mathrm{H}$ or $\mathrm{ZnO}: \mathrm{Al}$ interlayers are used, we study the plasmonic absorption losses in $\mathrm{Ag}$, $\mathrm{Al}$, and $\mathrm{Cr}$ when in contact with $\mathrm{a}-\mathrm{Si}: \mathrm{H}, \mathrm{SiO}_{\mathrm{x}}: \mathrm{H}$ or $\mathrm{ZnO}: \mathrm{Al}$. For this we represent the nanorough interface by a collection of nanosized metal spheres. This allows us to use the absorption efficiency $Q_{a b s}$ of the nanosphere calculated using Mie theory as a qualitative indication of the absorption at a nanorough interface. The results for spheres with a diameter of $40 \mathrm{~nm}$ are shown in Fig. 10. This clearly shows that for metal nanostructures the absorption can be strongly affected by plasmon resonance peaks, which are very different for $\mathrm{Ag}$, $\mathrm{Al}$, and Cr. Second, it shows that absorption in the metal is strongly dependent on the embedding medium. For all three metals, the absorption pattern shows a strong blue shift when the refractive index of the embedding medium is reduced (going from a-Si:H to $\mathrm{SiO}_{\mathrm{x}}: \mathrm{H}$ and finally to $\mathrm{ZnO}: \mathrm{Al}$ ). This is in agreement with the results presented by Palanchoke et al., ${ }^{20}$ who observed that an additional $\mathrm{ZnO}$ interlayer between the silicon solar cell and the metal back contact causes a shift of the localised plasmon resonances to shorter wavelengths. The wavelength range that is relevant for light trapping in a-Si:H solar cells is indicated in Fig. 10 by the horizontal arrows. Any absorption inside this range will negatively affect the red response of the solar cell. $\mathrm{Ag}$ and $\mathrm{Al}$, when in contact with a-Si:H, have plasmonic resonance

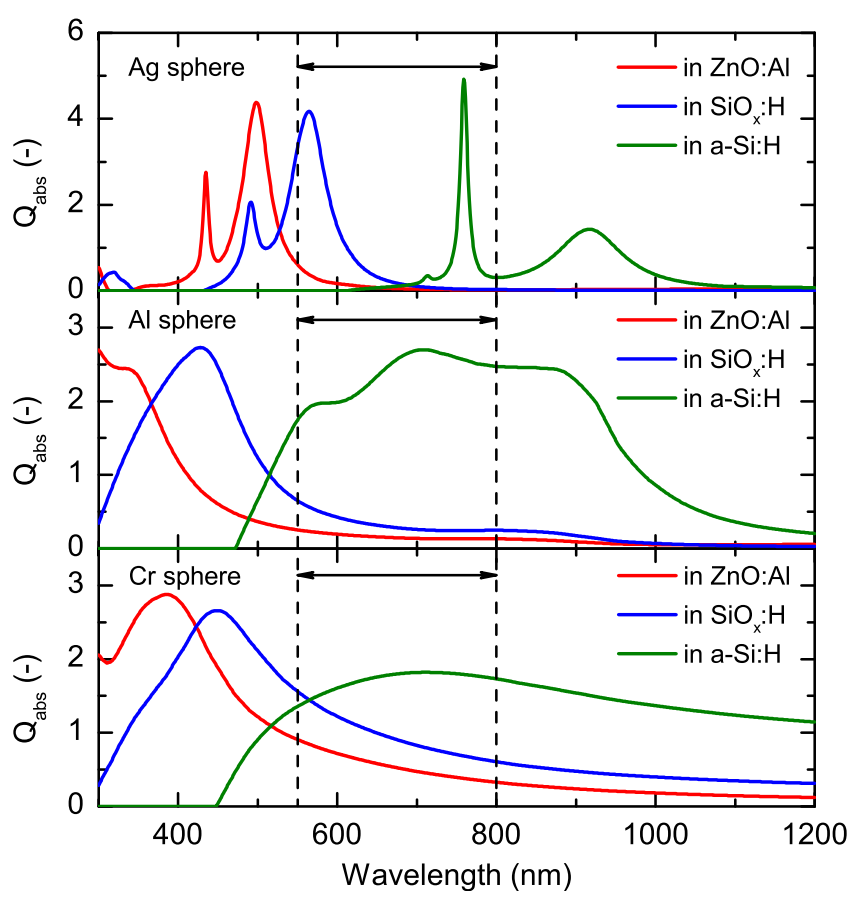

FIG. 10. The absorption efficiency as a function of the wavelength obtained from Mie theory of spherical Ag, Al, or Cr nanoparticles (diameter $40 \mathrm{~nm}$ ) embedded in $\mathrm{ZnO}: \mathrm{Al}$, SiOx:H, or a-Si:H. 
TABLE II. Solar cell performance changes due to different oxide BR configurations with respect to the reference solar cell that has no interlayers.

\begin{tabular}{lccccc}
\hline \hline & BR configuration & $\eta(\%)$ & $\Delta \eta^{\mathrm{a}}(\%)$ & $\Delta J_{s c}{ }^{\mathrm{a}}(\%)$ & $\Delta F F^{\mathrm{a}}(\%)$ \\
\hline Run 1 & $\mathrm{Ag}($ Ref. 1) & 8.7 & $\ldots$ & $\ldots$ & $\ldots$ \\
& $\mathrm{SiO}_{\mathrm{x}}: \mathrm{H} / \mathrm{Ag}$ & 9.4 & +8.0 & +7.6 & +0.7 \\
& $\mathrm{SiO}_{\mathrm{x}}: \mathrm{H} / \mathrm{ZnO}: \mathrm{Al} / \mathrm{Ag}$ & 9.7 & +11.5 & +10.8 & +0.8 \\
Run 2 & $\mathrm{Ag}(\mathrm{Ref.} 2)$ & 8.9 & $\ldots$ & $\ldots$ & $\ldots$ \\
& $\mathrm{ZnO}: \mathrm{Al} / \mathrm{Ag}$ & 9.5 & +6.7 & +9.4 & -2.7 \\
& $\mathrm{ZnO}: \mathrm{Al} / \mathrm{SiO}_{\mathrm{x}}: \mathrm{H} / \mathrm{Ag}$ & 9.1 & +2.4 & +9.7 & -7.7 \\
\hline \hline
\end{tabular}

${ }^{\text {a }}$ with respect to the reference

peaks in this relevant range. Ag has much sharper resonance peaks than Al. However, in both cases these peaks can be shifted below a wavelength of $550 \mathrm{~nm}$ by bringing the metal in contact with a low refractive index material like $\mathrm{ZnO}$ :Al. For $\mathrm{Cr}$, the absorption peaks are much broader and therefore more difficult to shift out of the relevant wavelength range completely. In addition, a small part of the absorption in $\mathrm{Al}$ and a significant part of the absorption in $\mathrm{Cr}$ are due to interband absorption, ${ }^{21}$ which unlike plasmonic absorption cannot be blue-shifted by reducing the refractive index of the embedding medium. The representation of the nanorough metal BR by nanosized metal spheres is a rather crude approximation. The real BR will contain many irregular features of different size and shape. Consequently, the real plasmonic absorption spectrum will look somewhat different from the spectra shown in Fig. 10. Therefore, this figure cannot be used to explain all deviations from the trend line shown in Fig. 9. It does however serve as an illustration of the manipulation of the plasmon resonance in $\mathrm{Ag}$ and $\mathrm{Al}$ nanostructures that can be achieved by including $\mathrm{ZnO}: \mathrm{Al}$ or $\mathrm{SiO}_{\mathrm{x}}: \mathrm{H}$ interlayers in the BR.

Table II summarises the relative enhancement of all the solar cell external parameters compared to the reference solar cell without oxide interlayer. Only the results for $\mathrm{Ag}$ are shown, since similar trends are observed for Al. The comparison between the single interlayers $\left(\mathrm{SiO}_{\mathrm{x}}: \mathrm{H}\right.$ and $\left.\mathrm{ZnO}: \mathrm{Al}\right)$ shows that both produce an improvement in solar cell performance. The incorporation of $\mathrm{ZnO}: \mathrm{Al}$ leads to a higher $J_{s c}$ enhancement, but the resulting $F F$ is reduced with respect to the reference solar cell. Although $\mathrm{SiO}_{\mathrm{x}}: \mathrm{H}$ gives a smaller increase in $J_{s c}$, it does not cause a reduction in $F F$, resulting in a larger $\eta$ improvement. Of all the analysed BR configurations, the best results were obtained for the configuration with the double interlayer $\mathrm{SiOx}: \mathrm{H} / \mathrm{ZnO}: \mathrm{Al}$ and $\mathrm{Ag}$ as the metal. Using this design, the largest improvement in $\eta$ (11.5\%) has been reached. This is mostly due to an enhanced red response of the solar cell.

\section{CONCLUSIONS}

We investigated the optical and electrical effects of the BR structure in $p-i-n$ a-Si:H solar cells. Using a unique inverse optical modeling approach, we derived the internal reflectance of $\mathrm{Ag}, \mathrm{Al}$, and $\mathrm{Cr}$ in different $\mathrm{BR}$ configurations for the wavelength range of $600-1200 \mathrm{~nm}$. Ag deposited onto an interlayer of $\mathrm{ZnO}: \mathrm{Al}$ or $\mathrm{SiO}_{\mathrm{x}}: \mathrm{H}$ has the highest reflectance around 95\% which is expected from the Fresnel equations. However, for $\mathrm{Ag}$ deposited directly onto a-Si:H and for any $\mathrm{BR}$ configuration with $\mathrm{Al}$ and $\mathrm{Cr}$, we find a reflectance that is significantly lower than the value given by the Fresnel equations. Since we used flat solar cells for this optical study, we can rule out that plasmonic absorption losses are the cause of the lower reflectance respect to the one expected.

We deposited a-Si:H solar cells with 15 different types of BRs on textured substrates. A correlation between the BR reflectances determined in the optical simulation study on flat samples and the performances of solar cells deposited on textured substrate has been identified. The BRs with $\mathrm{SiO}_{\mathrm{x}}: \mathrm{H}$ or $\mathrm{ZnO}: \mathrm{Al}$ interlayers and $\mathrm{Ag}$, for which we observed the highest reflectance, give the best red response of the solar cell. As expected, less reflective BRs also resulted in a lower red response. However, for the Ag and Al BRs without interlayers, the red response is still somewhat lower than expected. We attribute this to an additional reflectance loss due to plasmonic absorption in the metal that cannot be observed in the flat samples. We showed that the lower the refractive index of the interlayer, the further the plasmon resonance is shifted towards the blue part of the spectrum, where it cannot affect the red response of the solar cell. The BR does not affect $V_{o c}$, but can affect the $F F$. We observed that the $F F$ can be reduced somewhat when $\mathrm{ZnO}: \mathrm{Al}$ is deposited directly onto a-Si:H. The fact that this is not the case for $\mathrm{SiO}_{\mathrm{x}}: \mathrm{H}$, that moreover can be deposited by PECVD, makes $\mathrm{SiO}_{\mathrm{x}}: \mathrm{H}$ an interesting alternative to the commonly used $\mathrm{ZnO}: \mathrm{Al}$ interlayer. The largest $J_{s c}$ enhancement was found for double interlayers containing both a $\mathrm{SiO}_{\mathrm{x}}: \mathrm{H}$ and a $\mathrm{ZnO}: \mathrm{Al}$ layers. The configuration where $\mathrm{SiO}_{\mathrm{x}}: \mathrm{H}$ is deposited as the first layer, followed by the $\mathrm{ZnO}$ :Al layer, leads to both a high $J_{s c}$ and no reduction in $F F$ and therefore results in the highest $\eta$. This double interlayer combined with $\mathrm{Ag}$ gives rise to a conversion efficiency of $9.7 \%$, which is a relative enhancement of $11.5 \%$ compared to the reference solar cell without interlayers.

\section{ACKNOWLEDGMENTS}

The authors would like to thank Sergey Solntsev, Klaus Jäger and Pavel Babal for helpful discussions. This work is supported by Regione Autonoma della Sardegna (POR Sardegna FSE 2007-2013, L.R. 7/2007-2013 "Promozione della ricerca scientifica e dell'innovazione tecnologica in Sardegna”), by the Dutch Stichting Technische Wetenschappen VIDI grant of A. H. M. Smets "Innovative plasma processing for 2nd and 3rd generation photovoltaic materials" and by the Advanced Dutch Energy Materials project of Delft University of Technology.

${ }^{1}$ W. Beyer, J. Hüpkes, and H. Stiebig, Thin Solid Films 516, 147-154 (2007).

${ }^{2}$ A. M. K. Dagamseh, B. Vet, F. D. Tichelaar, P. Šutta, and M. Zeman, Thin Solid Films 516, 7844-7850 (2008).

${ }^{3}$ A. Banerjee and S. Guha, J. Appl. Phys. 69, 1030 (1991).

${ }^{4}$ G. Yue, L. Sivec, J. M. Owens, B. Yan, J. Yang, and S. Guha, Appl. Phys. Lett. 95, 263501 (2009).

${ }^{5}$ W. Bottler, V. Smirnov, J. Hüpkes, and F. Finger, Phys. Status Solidi A 209, 1144-1149 (2012). 
${ }^{6}$ U. Manna, J. Yoo, S. K. Dhungel, M. Gowtham, U. Gangopadhyay, K. Kim, and J. Yi, J. Korean Phys. Soc. 46(6), 1378-1382 (2005).

${ }^{7}$ M. Despeisse, G. Bugnon, A. Feltrin, M. Stueckelberger, P. Cuony, F. Meillaud, A. Billet, and C. Ballif, Appl. Phys. Lett. 96, 073507 (2010).

${ }^{8}$ P. Delli Veneri, L. V. Mercaldo, and I. Usatii, Appl. Phys. Lett. 97, 023512 (2010).

${ }^{9}$ C. Kothandaraman, T. Tonon, C. Huang, and A. E. Delahoy, Mater. Res. Symp. Proc. 219, 475-480 (1991).

${ }^{10}$ M. Zeman, R. A. C. M. M. van Swaaij, and J. W. Metselaar, J. Appl. Phys. 88, 6436 (2000).

${ }^{11}$ K. Jäger, M. Fischer, R. A. C. M. M. van Swaaij, and M. Zeman, J. Appl. Phys. 111, 083108 (2012)

${ }^{12}$ H. Stiebig, A. Kreisel, K. Winz, N. Schultz, C. Beneking, Th. Eickhoff, H. Wagner, and M. Meer, in Proceedings of the 1st World Conference on Photovoltaic Energy Conversion (IEEE Service Center, 1994), pp. 603-606.

${ }^{13}$ F.-J. Haug, T. Söderström, O. Cubero, V. Terrazzoni-Daudrix, and C. Ballif, J. Appl. Phys. 106, 044502 (2009).
${ }^{14}$ J. Springer, A. Poruba, L. Müllerova, M. Vaněček, O. Kluth, and B. Rech, J. Appl. Phys. 95, 1427-1429 (2004).

${ }^{15}$ F.-J. Haug, T. Söderström, O. Cubero, V. Terrazzoni-Daudrix, and C. Ballif, J. Appl. Phys. 104, 064509 (2008).

${ }^{16}$ H. Sai, H. Jia, and M. Kondo, J. Appl. Phys. 108, 044505 (2010).

${ }^{17}$ P. Babal, J. Blanker, R. Vasudevan, A. H. M. Smets, and M. Zeman, in Proceedings of 38th IEEE Photovoltaic Specialists Conference (PVSC) (IEEE, 2012).

${ }^{18}$ B. E. Pieters, J. Krč, and M. Zeman, in Conference Record of the 2006 IEEE 4th World Conference on Photovoltaic Energy Conversion (IEEE, Hawaii, 2006), pp. 1513-1516.

${ }^{19}$ E. D. Palik, Handbook of Optical Constants of Solids, 3rd ed. (Academic, New York, USA, 1998).

${ }^{20}$ U. Palanchoke, V. Jovanov, H. Kurz, P. Obermeyer, H. Stiebig, and D. Knipp, Opt. Express 20, 6340-6347 (2012).

${ }^{21}$ U. Kreibig and M. Vollmer, Optical Properties of Metal Clusters (Springer, Berlin, Germany, 1995). 